\title{
Encourage farmers to adopt sustainable water and nutrient management in arid agroecosystems: problems, solutions and future studies
}

Hadi Sareban, Ahad Madani*(D), Farshid Vazin

\section{Adress}

Department of Agronomy, Islamic Azad University, Gonabad Branch, Gonabad, Iran

* Corresponding author, Ahad Madani: madani ahad@yahoo.com

Received:19.03.2021; Accepted: 27.05.2021; Published: 27.05.2021

\section{ABSTRACT}

Crop production is seriously threatened by drought. Greater availability of nitrogen and phosphorus through intercropping with grain legumes and inoculationwith Phosphate Solubilizing Bactaeria (PSB) can alleviate the negative effect of water stress on some crops. However, row crop-grain legume intercropping and using PSB bacteria is not welcomed or widely accepted by smallholder farmers in arid regions. The problem is that $\mathrm{N}$-fixation by grain legumes cannot completely satisfy nitrogen demand of intercropped non-legume row crop especially in low phosphorus soils of these regions under restricted irrigation. The efficiency of PSB bacteria also is very low in the alkaline soil of this region. It suggests that some amount of nitrogen fertilizer should be used in this intercropping system. Nitrogen consumption also improves the efficiency of PSB bacteria. So, consumption of some mineral nitrogen, and incubation with PSB bacteria meet entirely the need for phosphorus fertilizer. Significant water saving by restricting irrigation without significant yield loss in row crop and grain legumes can be regarded as an advantage of this method. So, farmers can cultivate more land with the same amount of water. In such a situation, even small foliage of the grain legumes, as green manure, can convince the farmers to use the row crop -grain legumes intercropping system even under restricted irrigation conditions. Futures studies must focus on a better understanding of competition and facilitation of two crops for water and nutrients. They also must pay attention to nitrogen $\times$ PSB bacteria, and Phosphorus $\times$ rhizobacteria synergic interactions on yield and resources use efficiency of both crops. These studies may help to better water and plant nutrition management in a way that it is environmentally safe and economical for farmers. Keywords: Arid Regions, Agro-ecology, Fertilizer, Irrigation, Organic Farming

Organic farming benefits the environment builds healthy soil, supports water conservation and reduces field costs (Andrade et al., 2012; Wang et al., 2020). However, small-scale organic farming did not expectedly spread in arid regions (Min et al., 2017; Stepien et al., 2021). The main challenges of the organic farming systems in these regions include difficulties with soil nutrients and water management (Latati et al., 2017), and consequently a reduction in crop yield and farmers' incomes. Intercropping is an interesting technology in organic farming to provide nitrogen for the system, and the mixture of a nitrogen-fixing legume and non-legume crops is the most common intercrop combination (Latati et al., 2017; Dowling et al., 2021). However, grain legumes are poor $\mathrm{N}$-fixation crops in alkaline, Low-P and dry soils of arid regions (Jemo, et al., 2010; Lazali and Drevon, 2021). Although the use of PSB bacteria is considered as a solution to increase soil phosphorus, their efficiency is very low due to water restriction and low soil nitrogen (Ding et al., 2014; Hussian et al., 2021). These organic methods will not be welcomed by farmers without an appropriate solution to the problems expressed. The purpose of this review article is to describe the problem better, provide possible solutions and focus on future researches.

\section{DESCRIPTION OF PROBLEMS}

Crop production is seriously threatened by drought, especially in a climate change scenario and it may drastically affect world food security (Matiu et al., 2017). A variety of agronomic techniques such as intercropping (Andrade et al., 2012), organic matter (Jami et al., 2019), biochar (Paneque et al., 2016; Mannan et al., 2021), mulching (Zhao et al., 2016) and bio-fertilizers (Jalilian et al., 2012; Hosseinzadeh et al., 2021) w ith different results are used for row crops to alleviate water stress. The nitrogen and phosphorous uptake are hampered under moisture deficit stress (Dijkstra, et al., 2015), so greater availability of nitrogen through intercropping with grain legumes (Andrade et al., 2012), and phosphorus through incubation with PSB bacteria (Jalilian et al., 2012), can alleviate the negative effect of water stress on some crops.

The use of grain legumes grown in intercropping with sunflower, corn, cotton or other non-grain legumes row crops are recommended to farmers as an organic method for introducing nitrogen into low-input cropping systems in arid regions (Latati et al., 2017). However, it is not welcomed or widely accepted by smallholder farmers because it takes time for these intercropping systems to achieve significant net economic profit (Min et al., 2017). There are some other limitations with this intercropping system: phosphorus precipitates with calcium and magnesium ions in alkaline soils of these areas, and therefore, it is not mostly absorbable for root and nodules (Shen and Li, 2011). Grain legumes are poor nitrogen fixers in these soils because rhizobium bacteria cannot access to phosphorus (Jemo et al., 2010). Consequently, almost all these small amounts of fixed nitrogen directly enter the grain legume and there are only little leaks into the soil for a neighbouring nongrain legumes crop in intercropping (Corre-Hellou et al., 2006). Therefore, this method is only efficient when using the grain legumes as green manure in rotation (Plaza-Bonilla et al., 2016). However, because of the economic losses caused by the low 
grain yield of grain legumes in these low-phosphorus soils (Latati et al., 2017), the smallholder farmers are reluctant to use the grain legumes as green manure and still prefer to use them for forage (Douxchamps et al., 2013).

Limitation of absorbable $\mathrm{P}$ in these alkaline soils (Shen et al., 2011), $\mathrm{N}$ deficiency due to inadequate $\mathrm{N}$ fixation by grain legumes in low P soil (Jemo, et al., 2010), and water shortage in these semi-arid climates result in decreased grain yield of both crops due to intense intra-specific competition for these two nutrients and water (Latati et al., 2017; Corre-Hellou et al., 2006; Andrade et al., 2012). Yield loss of grain legumes is higher than row crop because the roots of the tall row crops such as sunflower, corn and cotton occupy soil both near the surface and in deep layers, whereas the roots of grain legumes are distributed in the upper soil layers (Albino-Garduno et al., 2015), thus sunflower, corn or cotton competitive ability for soil nitrogen, phosphorus and water is higher than that of grain legumes in intercropping system (Latati et al., 2017; Andrade et al., 2012). For this reason, it is not affordable for the smallholder farmers to harvest grain legume, but they rather use them as forage in crop-livestock systems (Douxchamps et al., 2014). Besides, nitrogen cannot return to the soil for the next crop in a rotation system through the decomposition of residues if all herbage is removed (Plaza-Bonilla et al., 2016). Description of problems is shown in Figure 1.

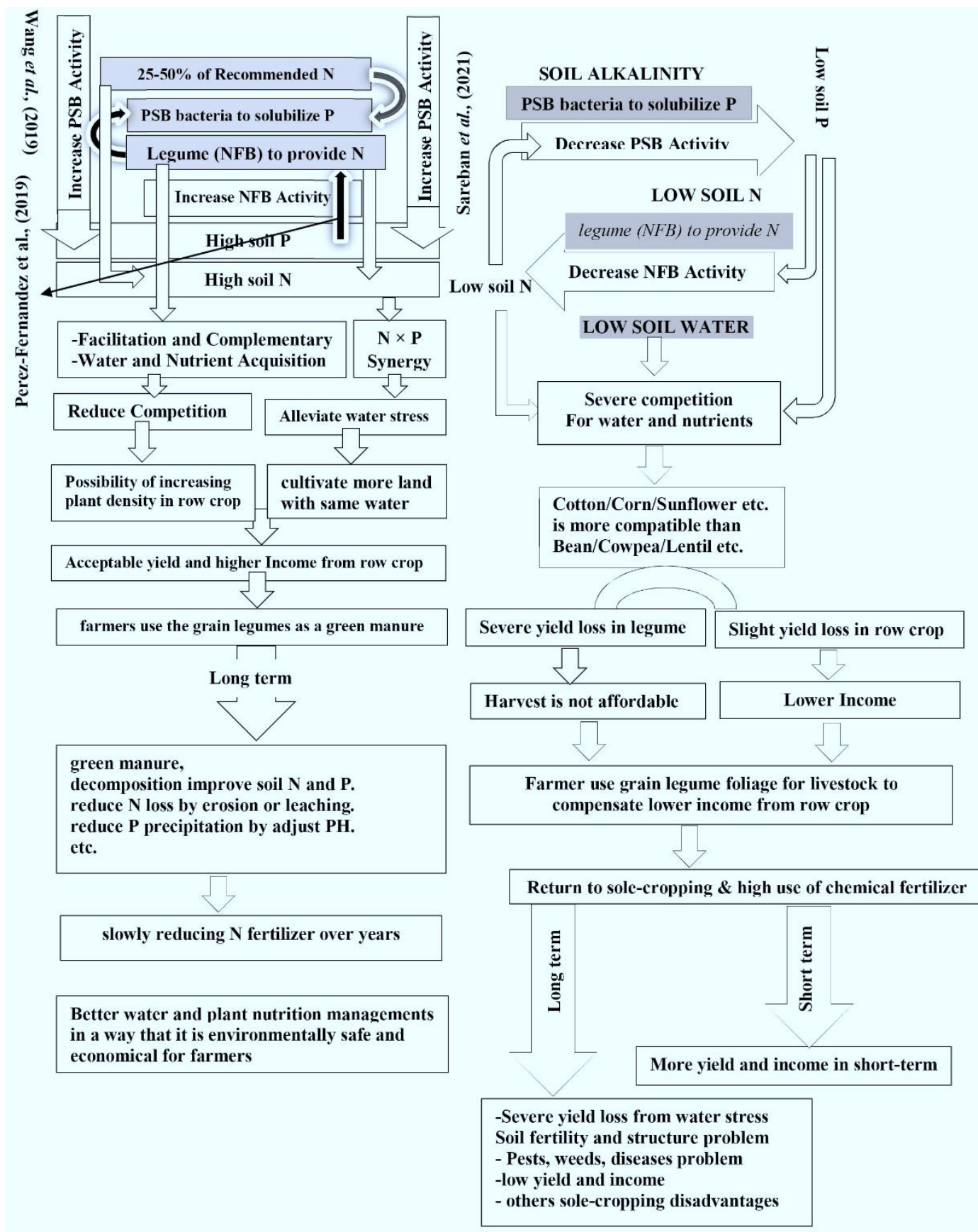

Figure 1. Description of Problems (right) and possible solutions (left) to sustainable water and nutrient management in arid agroecosystems. 


\section{POSSIBLE SOLUTIONS}

The spatial distribution of roots indicates the root interaction of nutrients and water in intercropping system (Albino-Garduno et al., 2015). nutrients have a relatively more uniform distribution in the soil layers, rather than water, which is more available in lower layers of the soil where sunflower, corn or cotton roots can access (Estrada et al., 2015). So, the competition between these two crops appears to be mainly for nutrients especially nitrogen and phosphorus rather than water. Accordingly, the consumption of some nitrogen and incubation with PSB under both moderate and restricted irrigation may be considered as a solution for increasing nitrogen fixation by grain legumes, decreasing competition for nitrogen and phosphorus between sunflower, corn or cotton with grain legumes, and yield loss in both of these crops, and alleviating water stress in this row crop-grain legumes intercropping system.

Moreover, significant water saving by restricting irrigation without significant yield loss in row crop and grain legumes can be regarded as another advantage of this method, so that farmers can cultivate more land with the same amount of water. In such a situation, even a small foliage of the grain legumes, as green manure can convince the farmers to use the row crop -grain legumes intercropping system even under restricted irrigation conditions. Grain legumes cultivation for its grain or forage plays a negligible role in providing non-grain legumes row crops such as sunflower, corn or cotton with nitrogen in this system (Douxchamps et al., 2014), but when it is used as green manure for long-term, it has very beneficial effects for the non-grain legumes row crops through increased organic matter, water retention in the soil, and nutrient availability (Plaza-Bonilla et al., 2016). These will gradually reduce nitrogen fertilizer and the amount of irrigation in this system over several years (Plaza-Bonilla et al., 2016; Douxchamps et al., 2014). Efficient acquisition of nutrients and water is another advantage of using the intercropping system. Supplying some of the nitrogen required by the intercropping system is not the only benefit of grain legumes. Grain legumes cultivation increases the availability of phosphorus and water for the system:

Grain legumes could increase secretion $\mathrm{H}$ ion in the soil via $\mathrm{N}$-fixation, this soil acidification improves the dissolution of phosphorous in low P soil. Li et al., (2016) reported that biomass and P uptake of the wheat in wheat-grain legumes intercropping were 1.3-1.9 and 1.9-2.3 times of mono-cropped wheat, respectively. Intercropping Promotes the Ability of Legume and Cereal to Facilitate Phosphorus and Nitrogen Acquisition through Root-Induced Processes (Latati et al., 2016). Intercropping enhance the spatial distribution of soil-water across roots, improves the coordination of soil-water sharing and provides the compensatory effect of available soil water, improvement of soil water content facilitates absorption of nitrogen, phosphorus and other nutrients from the soil.

Reducing competition is not the only advantage of using nitrogen in this system. nitrogen consumption improves the efficiency of PSB bacteria. Ding et al. (2014) reported that nitrogen increased inorganic phosphorus uptake in soils with low phosphorus by improving the PSB performance. It has been reported that increased resistance of photosynthesis to water stress at higher nitrogen conditions (Singh et al., 2016) in PSB incubated plants (Shintu and Jayaram, 2015) resulted from improved relative water content (RWC). Nitrogen $\times$ phosphorus interaction increases phosphorus uptake and consumption. Shen and Li (2011) also reported that water stress impaired PS II function in wheat, and this effect was significantly ameliorated by NP fertilizer but not $\mathrm{N}$ alone.

Eventually, phosphorus-related mechanisms such as better root system growth and synergy process induced by the $\mathrm{N} \times \mathrm{P}$ interaction result in increased relative water content (RWC) of the leaves and reduced chlorophyll fluorescence (Singh et al., 2016;), thereby preventing a significant decrease in the yield of row-crop and grain legumes under restricted irrigation, and leading to increased WUE and improved nitrogen and phosphorus absorption and their use efficiencies. Possible solutions is shown in Figure 1.

\section{FUTURE STUDIES}

Future studies aim to find an efficient and accruable solution to alleviate water stress and decrease grain yield loss of row crops and grain legumes under restricted irrigation in a row crops-grain legumes intercropping system by water and plant nutrition management in a way that is environmentally safe and economical for farmers. They also must investigate the synergic nitrogen $\times$ PSB bacteria or nitrogen $\times$ phosphorus interactions effect on yield and water and nutrient use efficiencies in the sole and intercropped row crops under both moderate and restricted irrigation. Research must also seek to find out how the grain legumes are mainly useful for this system: directly through N-Fixation, or indirectly by providing more soluble phosphorus and water in the soil for crops and finally, it deals with the competition and facilitation between row crops and grain legumes underdifferent water and nutrient management. Phosphate solubilizing microorganisms (PSMs) and nitrogen fixation bacteria (NFBs) from rhizosphere soil of different crop plants and their inteactiuon must be evaluated to better benefit the plant-microbe interactions in organic agriculture. Future research must find solutions to troubleshooting the Practical Challenges of Intercropping, and breeding varieties and cultivars that are better suited for growing as part of a mixed crop.

\section{CONCLUSION}

Row crop-grain legume intercropping and using PSB bacteria is not welcomed or widely accepted by smallholder farmers in arid regions. The efficiency of PSB bacteria also is very low in alkaline soil of this region. $\mathrm{N}$-fixation by grain legumes cannot satisfy nitrogen demand of row crop in low phosphorus soils of these regions under especially restricted irrigation.It can be concluded that intercropping with grain legumes, consumption of some nitrogen, and incubation with PSB bacteria increase PUE and completely meet the need for phosphorus fertilizer, alleviate water stress by P-related mechanisms and increase WUE. However, it seems that $\mathrm{N}$-fixation by grain legumes cannot completely satisfy the nitrogen demand of sunflower, corn or cotton especially under restricted irrigation, and some nitrogen fertilizer should be used in this intercropping system to 
decrease crops competition for nitrogen, and benefit from the $\mathrm{N} \times \mathrm{PSB}$ or $\mathrm{N} \times \mathrm{P}$ interactions to alleviate water stress. Significant water saving by restricting irrigation without significant yield loss in row crop and grain legumes can let farmers to cultivate more land with the same amount of water. In such a situation, even a small foliage of the grain legumes, as green manure can convince the farmers to use the row crop -grain legumes intercropping system even under restricted irrigation conditions. Future studies must focus on organic methods in irrigation and plant nutrition, in a way that is environmentally safe and economical for farmers.

Funding: Not applicable.

Conflict of Interest: The authors declare no conflict of interest

\section{REFERENCES}

Albino-Garduño, R., Turrent-Fernández, A., Isabel Cortés-Flores, J., Livera-Muñoz, M., \& Carmen Mendoza-Castillo, M. (2015). Root distribution and solar radiation in maize-bean intercropping systems. Agrociencia, 49(5), 513-531.

Andrade, J. F., Cerrudo, A., Rizzalli, R. H., \& Monzon, J. P. (2012). Sunflower-soybean intercrop productivity under different water conditions and sowing managements. Agronomy Journal, 104(4), 1049-1055. https://doi.org/10.1007/s10705$\underline{008-9187-x}$

Corre-Hellou, G., Fustec, J., \& Crozat, Y. (2006). Interspecific competition for soil N and its interaction with N2 fixation, leaf expansion and crop growth in pea-barley intercrops.Plant and Soil,282(1-2), $195-208$. https://doi.org/10.1007/s11104-005-5777-4

Dijkstra, F. A., He, M., Johansen, M. P., Harrison, J. J., \& Keitel, C. (2015). Plant and microbial uptake of nitrogen and phosphorus affected by drought using $15 \mathrm{~N}$ and 32P tracers. Soil Biology and Biochemistry, 82, $135-142$. https://doi.org/10.1016/i.soilbio.2014.12.021

Douxchamps, S., Rao, I. M., Peters, M., van der Hoek, R., Schmidt, A., Martens, S., ... Oberson, A. (2014). Farm-scale tradeoffs between legume use as forage versus green manure: The case of Canavalia brasiliensis. Agroecology and Sustainable Food Systems, 38(1), 25-45. https://doi.org/10.1080/21683565.2013.828667

Dowling, A., O Sadras, V., Roberts, P., Doolette, A., Zhou, Y., \& Denton, M. D. (2021, January 1). Legume-oilseed intercropping in mechanised broadacre agriculture - a review. Field Crops Research. Elsevier B.V. https://doi.org/10.1016/i.fcr.2020.107980

Ebrahimian, E., Seyyedi, S. M., Bybordi, A., \& Damalas, C. A. (2019). Seed yield and oil quality of sunflower, safflower, and sesame under different levels of irrigation water availability. Agricultural Water Management, 218, 149-157. https://doi.org/10.1016/i.agwat.2019.03.031

Jami, M. G., Baghbani-Arani, A., Karami Borz- Abad, R., \& Saadatkhah, A. (2019). Towards Improving the Vegetative and Qualitative Traits of Sunflower Using Amending Soil (Zeolite and Manure Farmyard) under Water Deficit Stress. Communications in Soil Science and Plant Analysis, 50(18), 2227-2237. https://doi.org/10.1080/00103624.2019.1651329

Jalilian, J., Modarres-Sanavy, S. A. M., Saberali, S. F., \& Sadat-Asilan, K. (2012). Effects of the combination of beneficial microbes and nitrogen on sunflower seed yields and seed quality traits under different irrigation regimes. Field Crops Research, 127, 26-34. $\quad$ https://doi.org/10.1016/i.fcr.2011.11.001

Jemo, M., Nolte, C., Tchienkoua, M., \& Abaidoo, R. C. (2010). Biological nitrogen fixation potential by soybeans in two low-P soils of southern Cameroon. Nutrient Cycling in Agroecosystems, 88(1), 49-58. https://doi.org/10.1007/s10705-008$\underline{9187-x}$

Hadi S., Madani A., \& Vazin, F., (2021) Response of cotton to irrigation, fertilization and plant density in a semi-arid region of IranResponse of cotton to irrigation, fertilization and plant density in a semi-arid region of Iran. Agric. Cons. Sci. (In Press)

Hussain, S., Sharif, M., \& Ahmad, W. (2021). Selection of efficient phosphorus solubilizing bacteria strains and mycorrhizea for enhanced cereal growth, root microbe status and $\mathrm{N}$ and $\mathrm{P}$ uptake in alkaline calcareous soil. Soil Science and Plant Nutrition. https://doi.org/10.1080/00380768.2021.1904793

Hosseinzadeh, M. H., Ghalavand, A., Boojar, M. M. A., Modarres-Sanavy, S. A. M., \& Mokhtassi-Bidgoli, A. (2021). Application of manure and biofertilizer to improve soil properties and increase grain yield, essential oil and $\omega 3$ of purslane (Portulaca oleracea L.) under drought stress. Soil and Tillage Research, 205. https://doi.org/10.1016/i.still.2020.104633

Lazali, M., \& Drevon, J. J. (2021). Mechanisms and Adaptation Strategies of Tolerance to Phosphorus Deficiency in Legumes. Communications in Soil Science and Plant Analysis. Bellwether Publishing, Ltd. https://doi.org/10.1080/00103624.2021.1885693

Latati, M., Aouiche, A., Tellah, S., Laribi, A., Benlahrech, S., Kaci, G., ... Ounane, S. M. (2017). Intercropping maize and common bean enhances microbial carbon and nitrogen availability in low phosphorus soil under Mediterranean conditions. European Journal of Soil Biology, 80, 9-18.

Li, C., Dong, Y., Li, H., Shen, J., \& Zhang, F. (2016). Shift from complementarity to facilitation on P uptake by intercropped wheat neighboring with faba bean when available soil $\mathrm{P}$ is depleted. Scientific Reports, 6. https://doi.org/10.1038/srep18663 
Mahmood, H. N., Towfiq, S. I., \& Rashid, K. A. (2019). The sensitivity of different growth stages of sunflower (Helianthus annuus L.) under deficit irrigation. Applied Ecology and Environmental Research, 17(4), 7605-7623. https://doi.org/10.15666/aeer/1704 76057623

Matiu, M., Ankerst, D. P., \& Menzel, A. (2017, May 1). Interactions between temperature and drought in global and regional crop yield variability during 1961-2014. PLOS ONE. Public Library of Science. https://doi.org/10.1371/journal.pone.0178339

Mannan, M. A., Mia, S., Halder, E., \& Dijkstra, F. A. (2021). Biochar application rate does not improve plant water availability in soybean under drought stress. Agricultural Water Management, 253. https://doi.org/10.1016/j.agwat.2021.106940

Min, S., Huang, J., Bai, J., \& Waibel, H. (2017). Adoption of intercropping among smallholder rubber farmers in Xishuangbanna, China. International Journal of Agricultural Sustainability, 15(3), 223-237. https://doi.org/10.1080/14735903.2017.1315234

Paneque, M., De la Rosa, J. M., Franco-Navarro, J. D., Colmenero-Flores, J. M., \& Knicker, H. (2016). Effect of biochar amendment on morphology, productivity and water relations of sunflower plants under non-irrigation conditions. Catena, 147, 280-287. https://doi.org/10.1016/i.catena.2016.07.037

USDA National Agricultural Statistics Service. (2014). Choice Reviews Online, 51(07), 51-3802-51-3802. https://doi.org/10.5860/choice.51-3802

Plaza-Bonilla, D., Nolot, J. M., Passot, S., Raffaillac, D., \& Justes, E. (2016). Grain legume-based rotations managed under conventional tillage need cover crops to mitigate soil organic matter losses. Soil and Tillage Research, 156, 33-43 .https://doi.org/10.1016/j.still.2015.09.021

Pérez-Fernández, M., Míguez-Montero, ángel, \& Valentine, A. (2019). Phosphorus and nitrogen modulate plant performance in shrubby legumes from the iberian peninsula. Plants, 8(9).

Shen, J., Yuan, L., Zhang, J., Li, H., Bai, Z., Chen, X., ... Zhang, F. (2011). Phosphorus dynamics: From soil to plant. Plant Physiology, 156(3), 997-1005. https://doi.org/10.1104/pp.111.175232

Shintu, P. V., \& Jayaram, K. M. (2015). Phosphate solubilising bacteria (Bacillus polymyxa) -An effective approach to mitigate drought in tomato (Lycopersicon esculentum Mill.). ISSN, 2(1), 2349-9265.

Wang, Z., Chen, Z., \& Fu, X. (2019). Integrated effects of co-inoculation with phosphate-solubilizing bacteria and n2-fixing bacteria on microbial population and soil amendment under $\mathrm{C}$ deficiency. International Journal of Environmental Research and Public Health, 16(13). https://doi.org/10.3390/ijerph16132442

Zhao, Y., Pang, H., Wang, J., Huo, L., \& Li, Y. (2014). Effects of straw mulch and buried straw on soil moisture and salinity in relation to sunflower growth and yield. Field Crops Research, 161, 16-25. https://doi.org/10.1016/i.fcr.2014.02.006 


\section{تشجيع المزارعين على الإدارة المستدامة للمياه والمغذيات في النظم الإيكولوجية الزراعية القاحلة: مراجعة مصغرة للمشاكل والحلول والدراسات المستقبلية \\ هادى صاربان، احد مدنى، فرشيد وزين \\ قسم الهندسة الزراعية ، جامعة آزاد الإسلامية ، فرع جونادال ، جوناباد ، إيران.

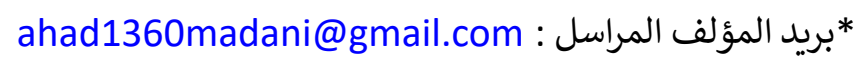

\section{الملخص العربى}

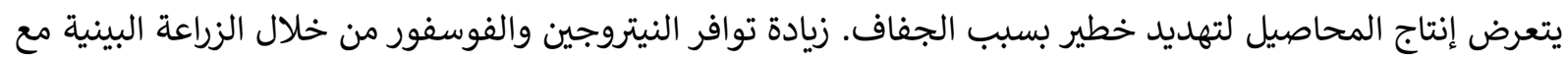

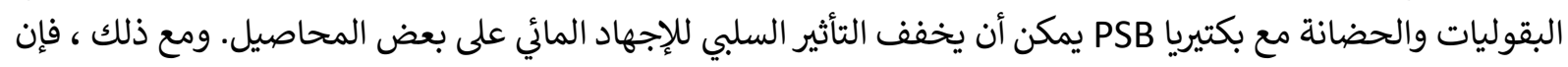

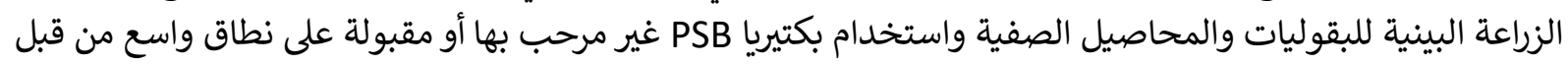

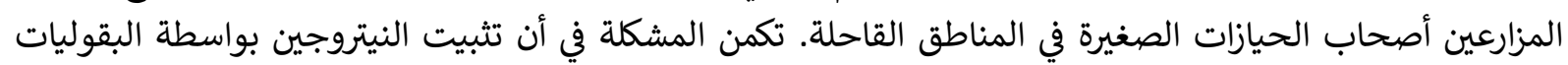

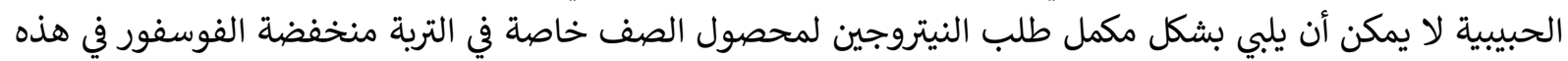

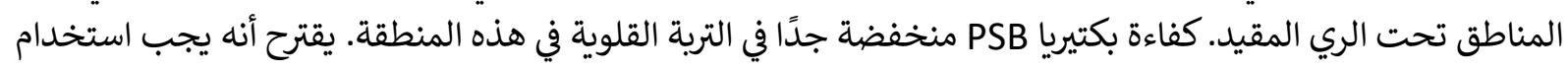

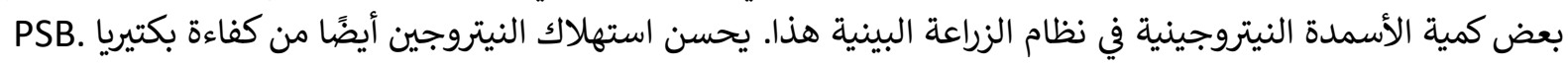

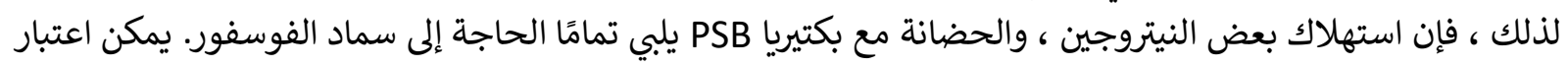

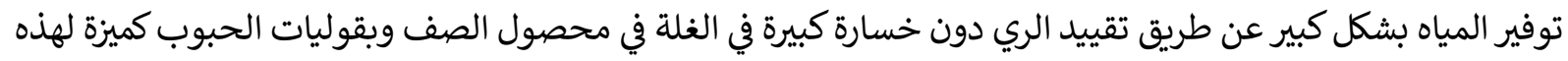

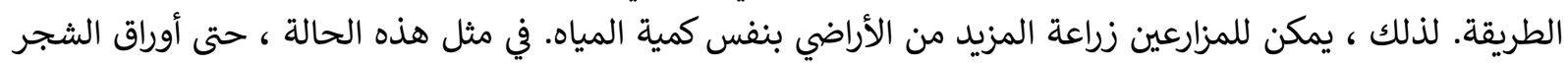

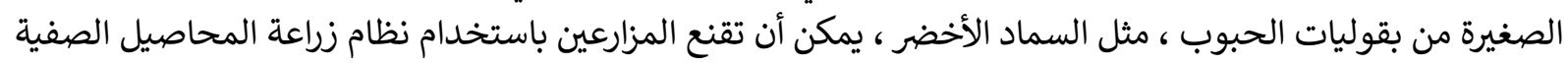

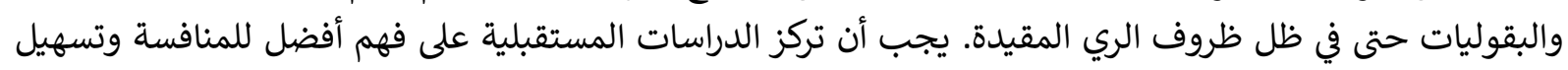

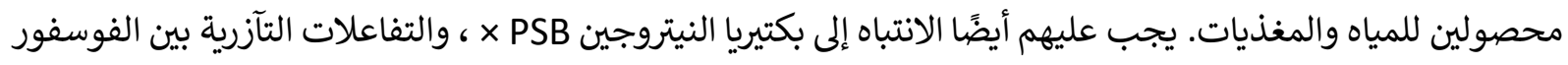

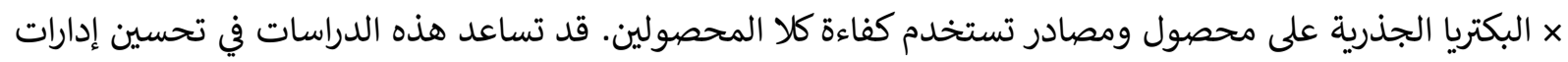
المياه وتغذية النبات بطريقة تكون آمنة بيئيًا واقتصادية للمزارعين.

الكلمات المفتاحية: المناطق الجافة ، الزراعة الإيكولوجية ، الأسمدة ، الري ، الزراعة العضوية 